\title{
Analisis Materi Ajar Kimia SMA/MA Kelas XII Pada Konsep Sifat Koligatif Larutan
}

\author{
Sri Haryati Wulandari*, Abdul Hadjranul Fatah, Maya Erliza Anggraeni \\ Program Studi Pendidikan Kimia, FKIP, Universitas Palangka Raya, Indonesia \\ E-mail: sriharyatiwulandari123@gmail.com
}

\begin{abstract}
ABSTRAK
Buku teks yang dianalisis yaitu 2 buku teks kimia SMA/MA Kelas XII. Instrumen yang digunakan yaitu tabel identifikasi relevansi antara teks asli dengan label konsep, tabel identifikasi proposisi mikro makro pada materi ajar, dan tabel identifikasi proposisi berpotensi kesalahan konsep. Data dianalisis secara deskriptif. Jumlah label konsep buku teks A yaitu 46 buah dan buku teks B yaitu 40 buah. Struktur makro wacana kedua buku teks, label konsep konsentrasi larutan dimensi elaborasi mencapai level 4, pengertian sifat koligatif larutan mencapai level 3, jenis-jenis sifat koligatif larutan mencapai level 6, dan penerapan sifat koligatif larutan mencapai level 4. Dimensi progresi kedua buku teks pada level 2 terdapat 4 konsep. Buku teks A, proposisi berpotensi kesalahan konsep mengandung konsep prasyarat yang salah. Buku teks B, proposisi berpotensi kesalahan konsep yaitu simbol kenaikan titik didih, titik didih, titik beku, dan penurunan titik beku. Beberapa contoh soal kedua buku teks tidak tertulis satuan.
\end{abstract}

Kata Kunci: sifat koligatif larutan, analisis konsep, stuktur makro wacana, proposisi berpotensi kesalahan konsep

\section{Pendahuluan}

Salah satu materi yang dimungkinkan munculnya miskonsepsi pada pemahaman siswa adalah materi sifat koligatif larutan, sebagian besar sumber belajar yang dibaca oleh siswa. Konsep-konsep abstrak pada materi ini meliputi gaya antarpartikel, perubahan fase, dan syarat dimilikinya tekanan uap oleh suatu zat cair. Kesalahan konsep pada materi ini telah banyak dilaporkan, di antaranya oleh Pinarbasi et al.(2009), Talanquer (2010), dan Luoga et al.(2013). Buku teks merupakan salah satu media pendidikan yang kedudukannya strategis dan ikut mempengaruhi mutu pendidikan, karena dapat berfungsi sebagai sumber belajar dan media yang sangat penting untuk mendukung tercapainya kompetensi yang menjadi tujuan pembelajaran. Sehubungan dengan hal itu seharusnya buku teks 
yang digunakan dapat menunjang dalam peningkatan hasil belajar dan mencerdaskan bangsa. Buku teks mempunyai peran sebagai perantara dalam sebuah proses pengajaran dan dianggap sebagai sumber informasi bagi siswa (Sothayapetch, 2013).

Buku siswa kimia untuk SMA/MA Kelas XII Peminatan Matematika dan Ilmu-Ilmu Alam ini telah dinyatakan layak digunakan berdasarkan Keputusan Menteri Pendidikan dan Kebudayaan Republik Indonesia Nomor 148/P/2016 Tahun 2016 Tanggal 1 Juli 2016 tentang "Penetapan Judul Materi ajar Pelajaran Kelompok Peminatan untuk SMA/MA”.

Buku ini digunakan berdasarkan Kurikulum 2013 edisi revisi 2016, baik secara materi maupun konsep pembelajarannya, dengan demikian, siswa akan memperoleh manfaat secara maksimal jika pembelajaran setiap materi dalam buku ini menggunakan pendekatan saintifik dengan mengaplikasikan pembelajaran berbasis aktivitas. Materi dalam Buku Siswa Kimia Berbasis Eksperimen 3 untuk Kelas XII SMA dan MA Peminatan Matematika dan Ilmu-Ilmu Alam telah disusun berdasarkan Kompetensi Dasar (KD) Kurikulum 2013 yang disempurnakan dan penyajian materi dalam buku mengutamakan data hasil eksperimen terlebih dahulu sebelum dibicarakan mengenai suatu teori.

Berdasarkan latar belakang di atas perlu diketahui seperti apa penyajian materi sifat koligatif larutan sebagai sumber belajar kimia yang digunakan siswa SMA/MA telah disajikan dengan baik dan benar, mengingat pentingnya peranan materi ajar dalam pembelajaran, maka perlu dikembangkan penelitian-penelitan tentang materi ajar yang saat ini sangat terbatas, sehingga Peneliti perlu untuk 
mengkaji penelitian dengan judul "Analisis Materi Ajar Kimia SMA/MA Kelas XII Pada Konsep Sifat Koligatif Larutan”.

Berdasarkan latar belakang yang di telah dikemukakan di atas, maka rumusan masalah untuk penelitian ini adalah:

1. Konsep-konsep apa yang terdapat dalam materi ajar kimia SMA/MA kelas XII pada konsep sifat koligatif larutan?

2. Bagaimana struktur makro wacana dalam materi ajar kimia SMA/MA kelas XII pada konsep sifat koligatif larutan?

3. Proposisi apa saja yang berpotensi menimbulkan kesalahan konsep yang terdapat dalam materi ajar kimia SMA/MA kelas XII pada konsep sifat koligatif larutan?

Penelitian ini bertujuan untuk mendeskripsikan: konsep-konsep yang terdapat dalam materi ajar kimia SMA/MA kelas XII pada konsep sifat koligatif larutan, struktur makro dalam materi ajar kimia SMA/MA kelas XII pada konsep sifat koligatif larutan, dan proposisi apa saja yang berpotensi kesalahan konsep dalam yang terdapat dalam materi ajar kimia SMA/MA kelas XII.

\section{Metodologi Penelitian}

Penelitian ini menggunakan metode deskriptif. Hal yang dideskripsikan dalam penelitian ini adalah hasil analisis materi ajar sifat koligatif larutan dalam materi ajar kimia SMA/MA kelas XII. Objek penelitian ini adalah adalah buku siswa kimia berbasis eksperimen 3 untuk kelas XII SMA dan MA kelompok peminatan matematika dan ilmu-ilmu alam karangan (Sentot dan Ispriyanto, 
2016) dan buku siswa kimia untuk SMA/MA Kelas XII peminatan matematika dan ilmu-ilmu alam karangan Anis, dkk (2016).

Data teks asli dan teks dasar dalam penelitian dikumpulkan dengan cara teks asli diambil dari masing-masing materi ajar kimia materi sifat koligatif larutan kurikulum 2013 dengan cara discan menggunakan printer dan diketik pada program microsoft word, teks asli yang discan dan diketik berupa konsep materi sifat koligatif larutan, teks asli dimasukan ke dalam tabel pembentukan teks dasar, dalam pembentukkan teks dasar dilakukan proses penghalusan melalui penghapusan dan penyisipan kata, teks asli diidentifikasi dengan menggunakan tabel identifikasi pada tabel 2 menggunakan lembar observasi (tabel identifikasi relevansi antara teks asli dengan label konsep pada materi ajar kimia SMA dengan bantuan program Microsoft Word) dan lembar observasi (tabel identifikasi proposisi mikro-makro pada materi ajar kimia SMA dengan bantuan program Microsoft Word). Data teks asli yang berpotensi menimbulkan kesalahan konsep diperoleh dengan lembar observasi (tabel identifikasi proposisi berpotensi kesalahan konsep dengan bantuan program Microsoft Word) melalui cara teks asli (konsep materi, contoh, dan soal) pada konsep materi sifat koligatif larutan yang dianalisis ditelaah secara cermat, setelah ditelaah secara keseluruhan pada teks asli dapat ditemukan proposisi yang berpotensi kesalahan konsep, dan teks asli yang berpotensi menimbulkan kesalahan konsep discan menggunakan printer dan diketik pada program microsoft word, dan proposisi berpotensi kesalahan konsep diidentifikasi dengan menggunakan tabel identifikasi pada tabel 3. Teknik analisis data dalam penelitian ini adalah data teks dasar dianalisis secara deskriptif dengan langkah-langkah sebagai berikut: 
a. Pada proses penghapusan dilakukan untuk menghilangkan kata-kata yang tidak diperlukan sehingga akan menghasilkan proposisi mikro dan makro

b. Pada proses generalisasi dapat diturunkan dari proposisi tertentu sehingga dihasilkan proposisi makro yang bersifat umum

c. Pada proses konstruksi dapat dihasilkan proposisi baru, yaitu proposisi makro dibangun dari beberapa proposisi mikro

Proposisi makro utama yang dihasilkan akan dilakukan pemetaan ke dalam struktur makro wacana menggunakan Program Microsoft Word. Teknik analisis data teks teks asli yang berpotensi menimbulkan kesalahan konsep dianalisis secara deskriptif dengan teks asli yang berpotensi menimbulkan kesalahan konsep dilakukan analisis dengan cara peneliti memberikan konsepsi peneliti berupa konsepsi peneliti, menunjukkan teks yang berpotensi miskonsepsi, dan alasan penentuan materi yang berpotensi kesalahan konsep.

\section{Hasil Penelitian Dan Pembahasan}

Penelitian ini akan dijelaskan hasil dan pembahasan mengenai hubungan kesesuaian label konsep masing-masing buku pada materi sifat koligatif larutan. Kesesuaian konsep sifat koligatif larutan dipaparkan pada tabel 9.

Tabel 9. Perbandingan Label Konsep Pada Setiap Buku Teks

\begin{tabular}{lllccc}
\hline No & \multicolumn{1}{c}{ Label konsep } & \multicolumn{2}{c}{ Buku Teks A } & \multicolumn{2}{c}{ Buku Teks B } \\
\cline { 3 - 6 } & \multicolumn{1}{c}{$\begin{array}{c}\text { Jenis } \\
\text { pengetahuan }\end{array}$} & $\begin{array}{c}\sqrt{\text { atau }} \\
\text { nenerapan sifat }\end{array}$ & $\begin{array}{c}\text { Jenis } \\
\text { pengetahuan }\end{array}$ & $\sqrt{\text { atau - }}$ \\
\hline 1 & $\begin{array}{l}\text { Penetar } \\
\text { koligatif larutan } \\
\text { pada pembuatan es } \\
\text { puter }\end{array}$ & Metakognitif & $\sqrt{ }$ & - & - \\
\hline 2 & $\begin{array}{l}\text { Pengertian sifat } \\
\text { koligatif larutan }\end{array}$ & Konseptual & $\sqrt{ }$ & Konseptual & $\sqrt{ }$ \\
\hline 3 & Konsentrasi larutan & Faktual & $\sqrt{ }$ & Konseptual & $\sqrt{ }$ \\
\hline
\end{tabular}




\begin{tabular}{|c|c|c|c|c|c|}
\hline 4 & $\begin{array}{l}\text { Definisi konsentrasi } \\
\text { larutan }\end{array}$ & Konseptual & $\sqrt{ }$ & - & - \\
\hline 5 & Definisi polaritas & Konseptual & $\sqrt{ }$ & - & - \\
\hline 6 & Rumus molaritas & Konseptual & $\sqrt{ }$ & - & - \\
\hline 7 & Definisi molalitas & Konseptual & $\sqrt{ }$ & - & - \\
\hline 8 & Rumus molalitas & Konseptual & $\sqrt{ }$ & Konseptual & - \\
\hline 9 & $\begin{array}{l}\text { Penerapan sifat } \\
\text { koligatif larutan } \\
\text { pada pembuatan } \\
\text { kolam apung }\end{array}$ & Faktual & $\sqrt{ }$ & - & - \\
\hline 10 & $\begin{array}{l}\text { Penerapan sifat } \\
\text { koligatif larutan } \\
\text { saat merebus mi }\end{array}$ & Faktual & $\sqrt{ }$ & - & - \\
\hline 11 & Definisi fraksi mol & Konseptual & $\sqrt{ }$ & Konseptual & $\sqrt{ }$ \\
\hline 12 & Rumus fraksi mol & Konseptual & $\sqrt{ }$ & Konseptual & $\sqrt{ }$ \\
\hline 13 & $\begin{array}{l}\text { Definisi sifat } \\
\text { koligatif larutan }\end{array}$ & $\begin{array}{l}\text { Konseptual } \\
\text { Metakognitif } \\
\text { Prosedural } \\
\text { Faktual } \\
\end{array}$ & $\sqrt{ }$ & - & - \\
\hline 14 & $\begin{array}{l}\text { Sifat koligatif } \\
\text { larutan } \\
\text { nonelektrolit }\end{array}$ & Konseptual & $\sqrt{ }$ & Konseptual & $\sqrt{ }$ \\
\hline 15 & $\begin{array}{l}\text { Pengertian tekanan } \\
\text { uap larutan }(\mathrm{P})\end{array}$ & Konseptual & $\sqrt{ }$ & $\begin{array}{l}\text { Konseptual } \\
\text { Faktual }\end{array}$ & $\sqrt{ }$ \\
\hline 16 & $\begin{array}{l}\text { Pengertian } \\
\text { penurunan tekanan } \\
\text { uap }(\Delta \mathrm{P})\end{array}$ & Konseptual & $\sqrt{ }$ & Konseptual & $\sqrt{ }$ \\
\hline 17 & $\begin{array}{l}\text { Rumus penurunan } \\
\text { tekanan uap }(\Delta \mathrm{P})\end{array}$ & Konseptual & $\sqrt{ }$ & Konseptual & $\sqrt{ }$ \\
\hline 18 & $\begin{array}{l}\text { Jenis-jenis sifat } \\
\text { koligatif larutan }\end{array}$ & $\begin{array}{l}\text { Konseptual } \\
\text { Metakognitif }\end{array}$ & $\sqrt{ }$ & Konseptual & - \\
\hline 19 & $\begin{array}{l}\text { Rumus tekanan uap } \\
\text { larutan }(\mathrm{P})\end{array}$ & Konseptual & $\sqrt{ }$ & Konseptual & - \\
\hline 20 & Hukum Raoult & Konseptual & $\sqrt{ }$ & Konseptual & $\sqrt{ }$ \\
\hline 21 & $\begin{array}{l}\text { Tekanan parsial } \\
\text { pelarut }\end{array}$ & Konseptual & $\sqrt{ }$ & - & - \\
\hline 22 & Tekanan uap total & Konseptual & $\sqrt{ }$ & - & - \\
\hline 23 & Titik beku & $\begin{array}{l}\text { Konseptual } \\
\text { Metakognitif }\end{array}$ & $\sqrt{ }$ & Konseptual & $\sqrt{ }$ \\
\hline 24 & $\begin{array}{l}\text { Pengertian } \\
\text { penurunan } \\
\text { beku }\left(\Delta \mathrm{T}_{\mathrm{f}}\right)\end{array}$ & Konseptual & $\sqrt{ }$ & Konseptual & $\sqrt{ }$ \\
\hline 25 & $\begin{array}{l}\text { Diagram fase untuk } \\
\text { air dan larutan }\end{array}$ & Konseptual & $\sqrt{ }$ & Konseptual & $\sqrt{ }$ \\
\hline 26 & $\begin{array}{l}\text { Tetapan penurunan } \\
\text { titik beku molal }\end{array}$ & $\begin{array}{l}\text { Konseptual } \\
\text { Faktual }\end{array}$ & $\sqrt{ }$ & Konseptual & $\sqrt{ }$ \\
\hline
\end{tabular}




\begin{tabular}{|c|c|c|c|c|c|}
\hline & $\left(\mathrm{K}_{\mathrm{f}}\right)$ & & & & \\
\hline 27 & $\begin{array}{l}\text { Rumus penurunan } \\
\text { titik beku }\left(\Delta \mathrm{T}_{\mathrm{f}}\right)\end{array}$ & Konseptual & $\sqrt{ }$ & Konseptual & $\sqrt{ }$ \\
\hline 28 & Zat antibeku & Faktual & $\sqrt{ }$ & Faktual & $\sqrt{ }$ \\
\hline 29 & Titik didih & Konseptual & $\sqrt{ }$ & Konseptual & $\sqrt{ }$ \\
\hline 30 & $\begin{array}{l}\text { Pengertian } \\
\text { kenaikan titik didih } \\
\left(\Delta \mathrm{T}_{\mathrm{b}}\right)\end{array}$ & Konseptual & $\sqrt{ }$ & Konseptual & $\sqrt{ }$ \\
\hline 31 & $\begin{array}{l}\text { Tetapan kenaikan } \\
\text { titik didih molal } \\
\left(\mathrm{K}_{\mathrm{b}}\right)\end{array}$ & Konseptual & $\sqrt{ }$ & Konseptual & $\sqrt{ }$ \\
\hline 32 & $\begin{array}{l}\text { Rumus kenaikan } \\
\text { titik didih }\left(\Delta \mathrm{T}_{\mathrm{b}}\right)\end{array}$ & $\begin{array}{l}\text { Konseptual } \\
\text { Faktual }\end{array}$ & $\sqrt{ }$ & Konseptual & $\sqrt{ }$ \\
\hline 33 & $\begin{array}{l}\text { Penerapan sifat } \\
\text { koligatif larutan } \\
\text { pada pencairan } \\
\text { salju }\end{array}$ & - & & Faktual & $\sqrt{ }$ \\
\hline 34 & Osmosis & Konseptual & $\sqrt{ }$ & Konseptual & $\sqrt{ }$ \\
\hline 35 & $\begin{array}{l}\text { Pengertian tekanan } \\
\text { osmotik }(\pi)\end{array}$ & Konseptual & $\sqrt{ }$ & Konseptual & $\sqrt{ }$ \\
\hline 36 & Isotonik & Konseptual & $\sqrt{ }$ & Konseptual & $\sqrt{ }$ \\
\hline 37 & Hipotonik & Konseptual & $\sqrt{ }$ & Konseptual & $\sqrt{ }$ \\
\hline 38 & Hipertonik & Konseptual & $\sqrt{ }$ & Konseptual & $\sqrt{ }$ \\
\hline 39 & $\begin{array}{l}\text { Peristiwa alam } \\
\text { yang melibatkan } \\
\text { osmosis }\end{array}$ & Faktual & $\sqrt{ }$ & Faktual & $\sqrt{ }$ \\
\hline 40 & $\begin{array}{l}\text { Rumus tekanan } \\
\text { osmotik }(\pi)\end{array}$ & Konseptual & $\sqrt{ }$ & Konseptual & $\sqrt{ }$ \\
\hline 41 & $\begin{array}{l}\text { Sifat koligatif } \\
\text { larutan elektrolit }\end{array}$ & Konseptual & $\sqrt{ }$ & Konseptual & $\sqrt{ }$ \\
\hline 42 & $\begin{array}{l}\text { Derajat pengionan } \\
(\alpha)\end{array}$ & $\begin{array}{l}\text { Metakognitif } \\
\text { Konseptual }\end{array}$ & $\sqrt{ }$ & $\begin{array}{l}\text { Konseptual } \\
\text { Faktual } \\
\text { Prosedural } \\
\end{array}$ & $\sqrt{ }$ \\
\hline 43 & $\begin{array}{l}\text { Faktor van't Hoff } \\
\text { (i) }\end{array}$ & Prosedural & $\sqrt{ }$ & Konseptual & $\sqrt{ }$ \\
\hline 44 & $\begin{array}{l}\text { Rumus penurunan } \\
\text { tekanan uap }(\Delta \mathrm{P}) \\
\text { larutan elektrolit }\end{array}$ & Konseptual & $\sqrt{ }$ & - & \\
\hline 45 & $\begin{array}{l}\text { Rumus penurunan } \\
\text { titik beku }\left(\Delta \mathrm{T}_{\mathrm{f}}\right) \\
\text { larutan elektrolit }\end{array}$ & Konseptual & $\sqrt{ }$ & Konseptual & $\sqrt{ }$ \\
\hline 46 & $\begin{array}{l}\text { Rumus kenaikan } \\
\text { titik didih larutan } \\
\text { elektrolit }\left(\Delta \mathrm{T}_{\mathrm{b}}\right)\end{array}$ & Konseptual & $\sqrt{ }$ & Konseptual & $\sqrt{ }$ \\
\hline 47 & Molalitas & - & - & Konseptual & $\sqrt{ }$ \\
\hline 48 & Rumus tekanan & Konseptual & $\sqrt{ }$ & Konseptual & $\sqrt{ }$ \\
\hline
\end{tabular}


Sri Haryati Wulandari (300-320)

\begin{tabular}{llllll}
\hline & $\begin{array}{l}\text { osmotik }(\pi) \text { larutan } \\
\text { elektrolit }\end{array}$ & & & & \\
\hline 49 & $\begin{array}{l}\text { Selaput } \\
\text { semipermeabel }\end{array}$ & - & - & Konseptual & $\sqrt{ }$ \\
\hline 50 & $\begin{array}{l}\text { Pengertian osmosis } \\
\text { balik }\end{array}$ & - & - & Konseptual & $\sqrt{ }$ \\
\hline 51 & $\begin{array}{l}\text { Penerapan osmosis } \\
\text { balik }\end{array}$ & - & - & Konseptual & $\sqrt{ }$ \\
\hline
\end{tabular}

Berdasarkan tabel diatas label konsep yang dipaparkan pada buku teks A berjumlah 46 buah dan jumlah label konsep pada buku teks B yaitu 40 buah. Label konsep yang tidak tercantum di buku teks A tetapi tercantum di buku teks B yaitu selaput semipermeabel, pengertian osmosis terbalik, dan penerapan osmosis terbalik. Label konsep yang tidak tercantum dibuku teks B tetapi tercantum di buku teks A yaitu penerapan sifat koligatif larutan pencairan salju di jalan raya, definisi konsentrasi, definisi molaritas, rumus molaritas, definisi molalitas, definisi sifat koligatif larutan, tekanan parsial pelarut, tekanan uap total, dan rumus penurunan tekanan uap $(\Delta \mathrm{P})$ larutan elektrolit. 
Vol.10 No.02

\section{Struktur Makro Wacana Buku Teks A}

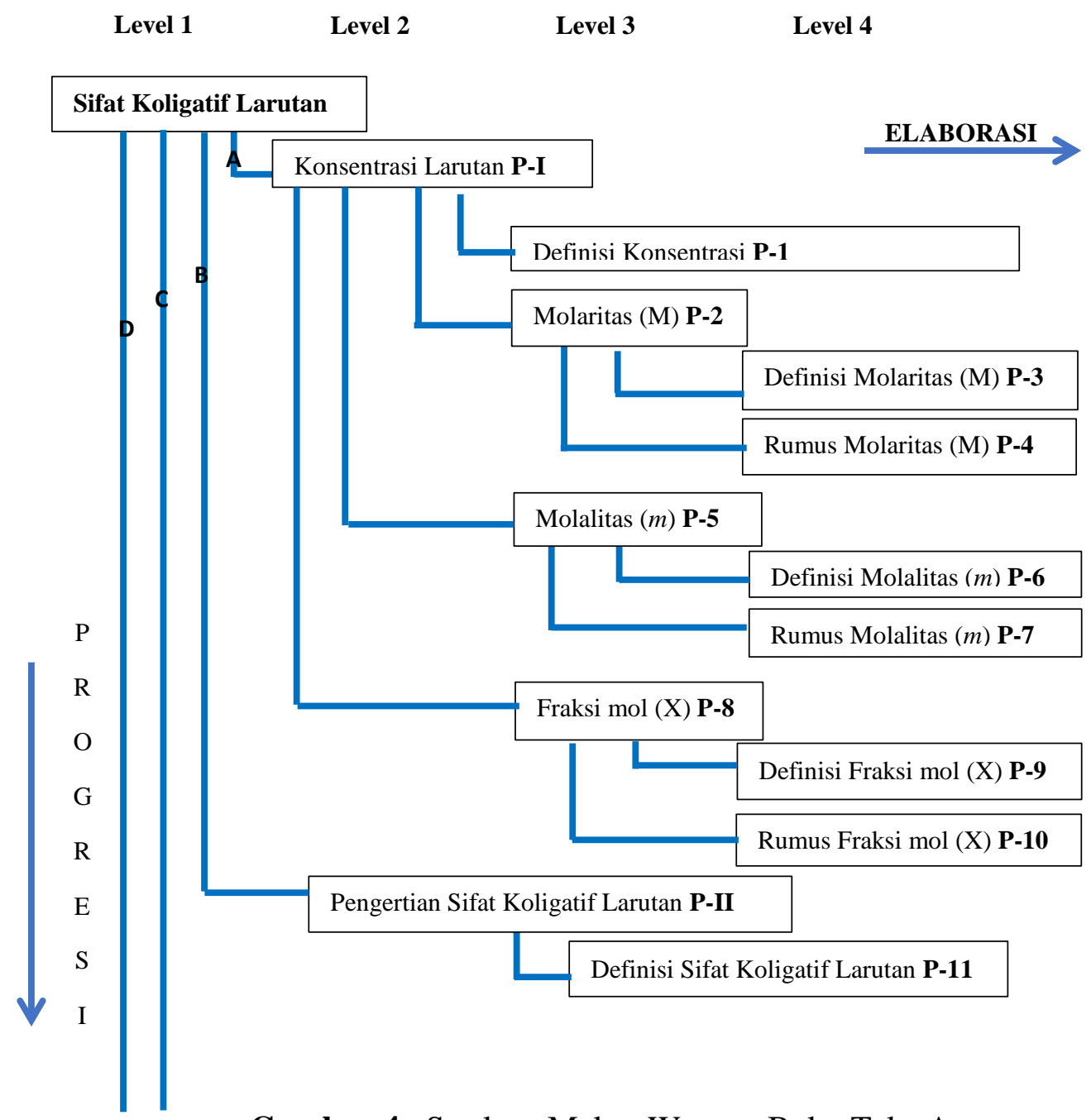

Gambar 4. Struktur Makro Wacana Buku Teks A 
$\begin{array}{llllll}\text { Level } 1 & \text { Level } 2 & \text { Level } 3 & \text { Level } 4 & \text { Level } 5 & \text { Level } 6\end{array}$

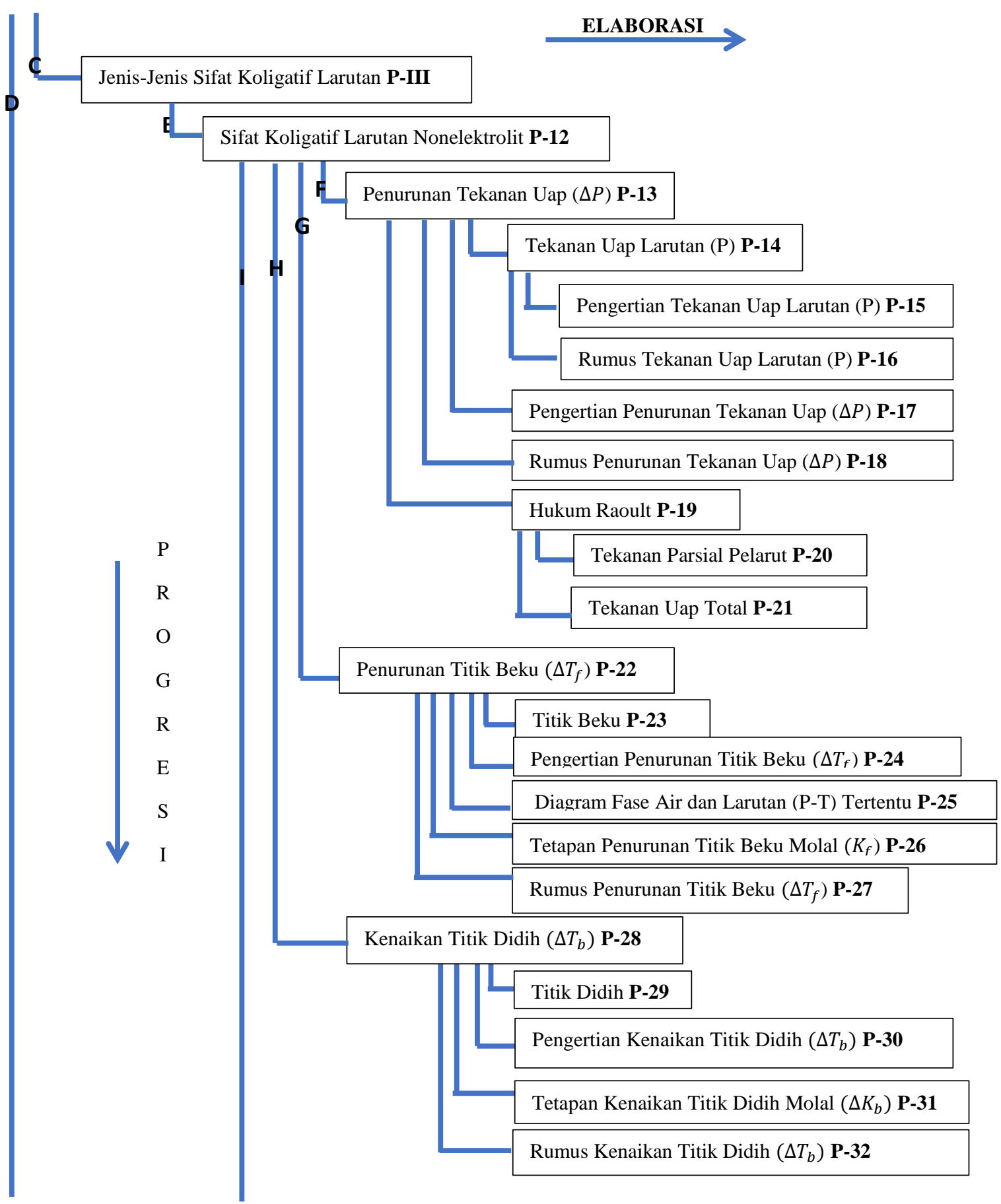

Gambar 4. Struktur Makro Wacana Buku Teks A (Lanjutan) 


\section{$\begin{array}{llllrr}\text { Level } 1 & \text { Level } 2 & \text { Level } 3 & \text { Level } 4 & \text { Level } 5 & \text { Level } 6\end{array}$}

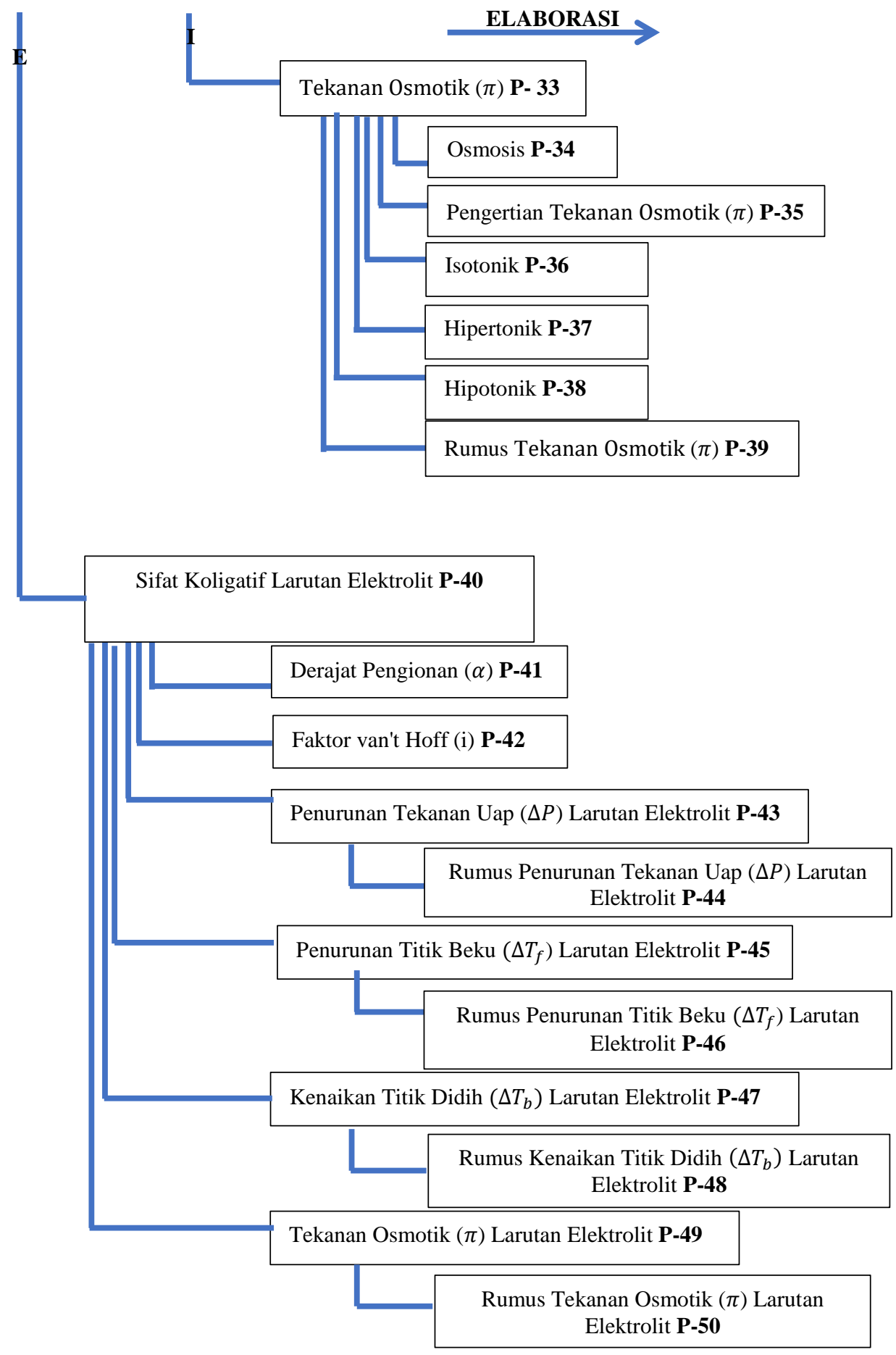

Gambar 4. Struktur Makro Wacana Buku Teks A (Lanjutan) 
Sri Haryati Wulandari (300-320)

Level 1 Level $2 \quad$ Level $3 \quad$ Level 4

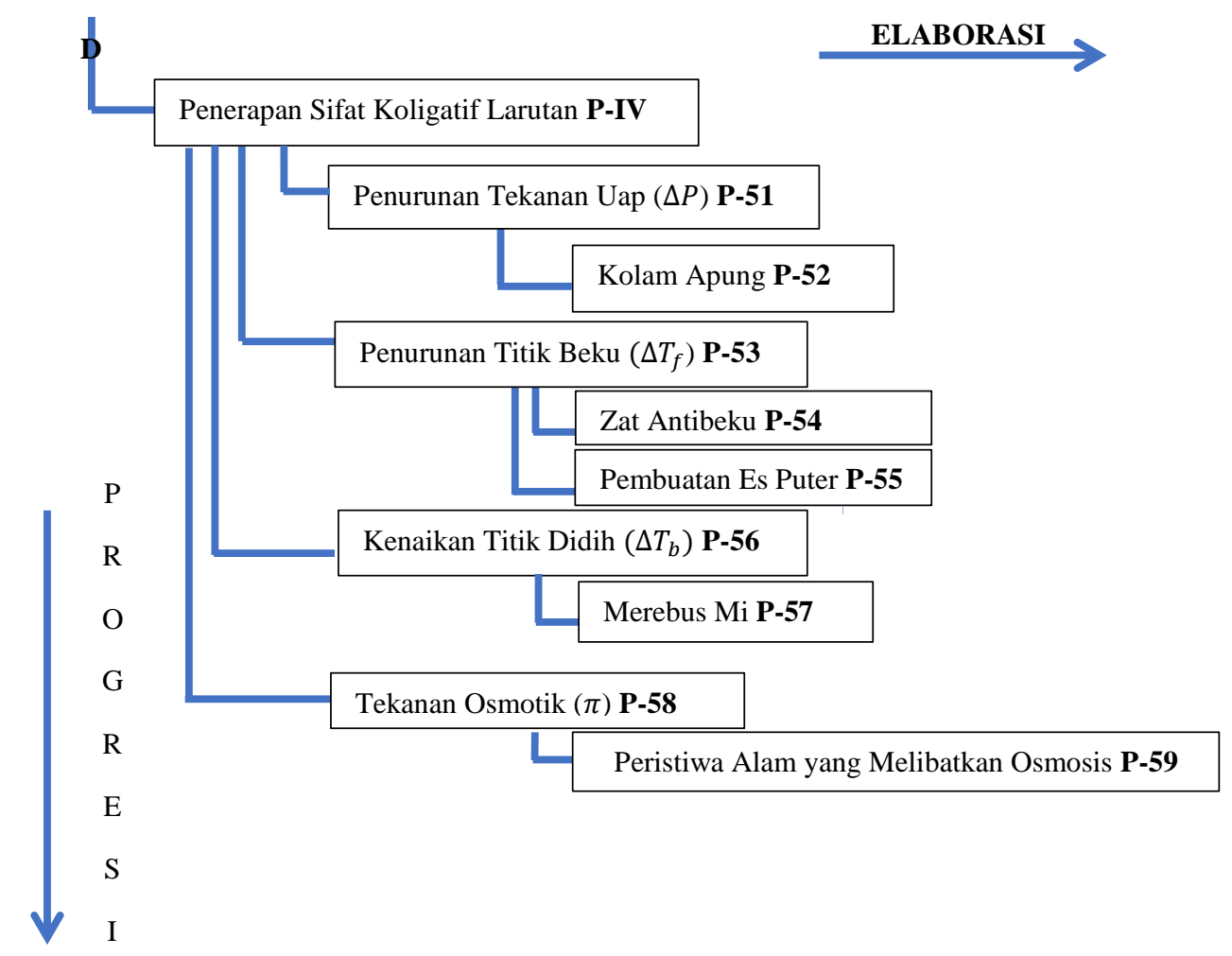

Gambar 4. Struktur Makro Wacana Buku Teks A (Lanjutan) 


\section{Stukrur Makro Wacana Buku Teks B}

Level 1 Level 2 Level $3 \quad$ Level $4 \quad$ Level 5 Level 6

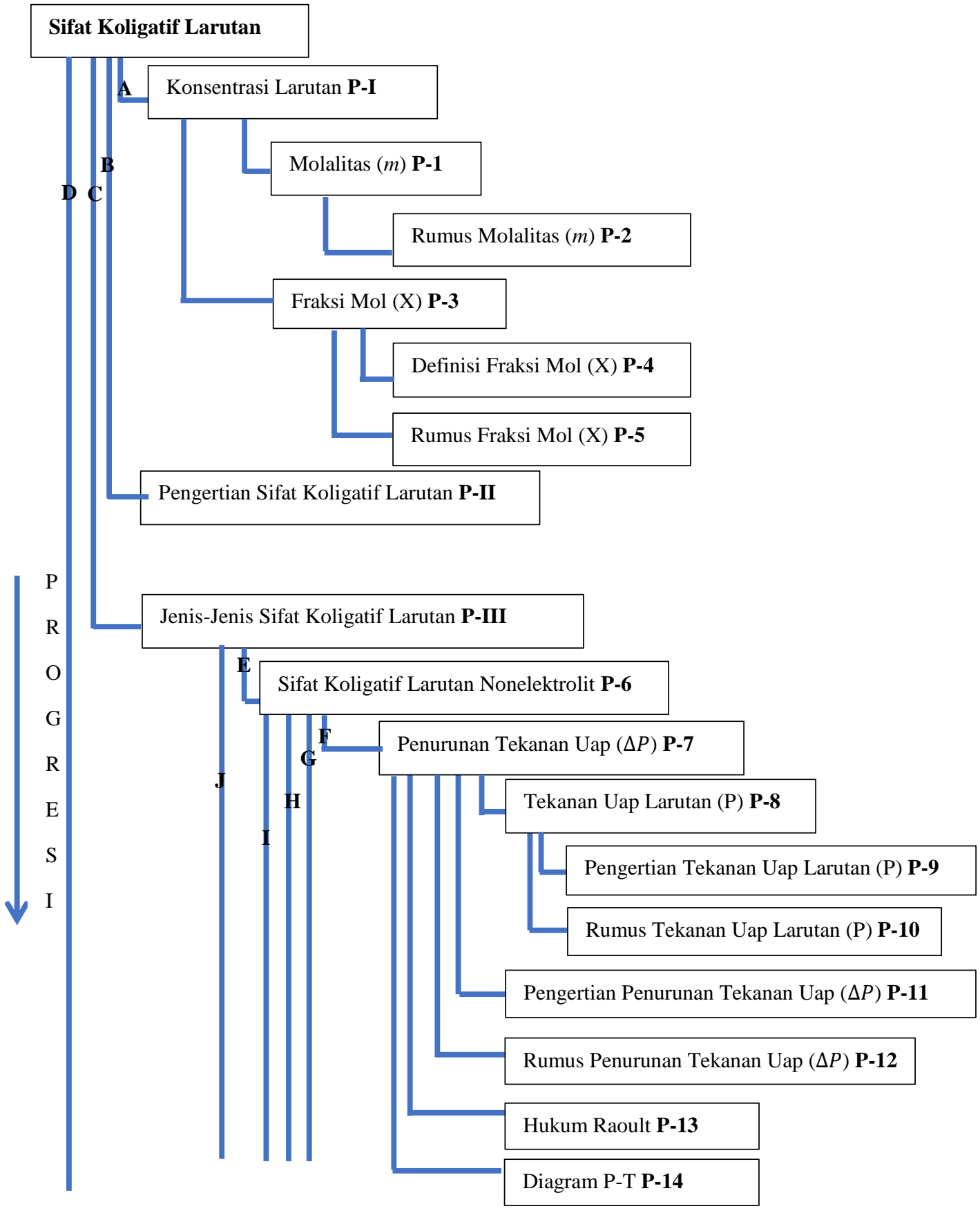

Gambar 5. Struktur Makro Wacana Buku Teks B 


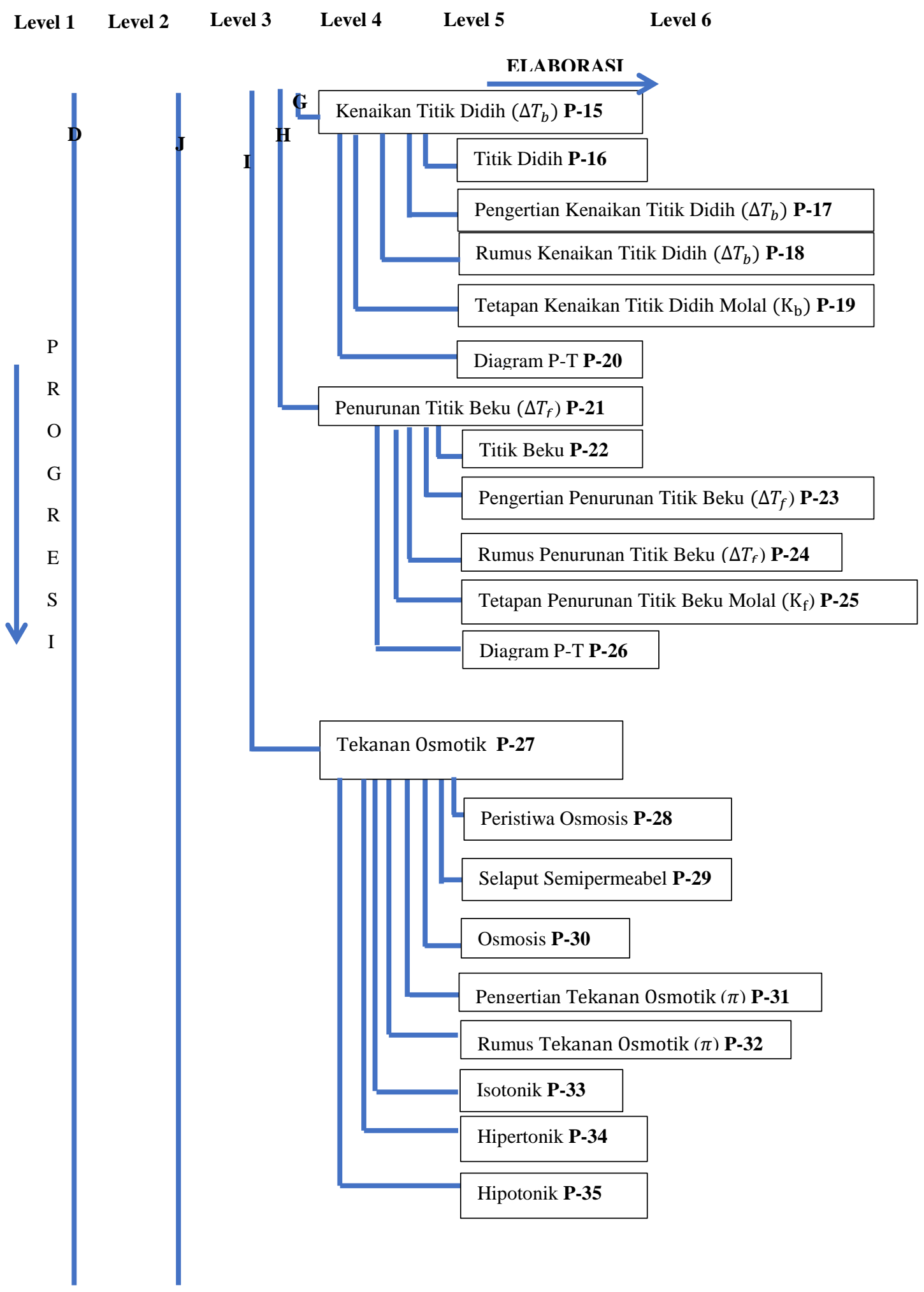

Gambar 5. Struktur Makro Wacana Buku Teks B (Lanjutan) 


\section{Level 1 Level 2 Level $3 \quad$ Level $4 \quad$ Level 5}

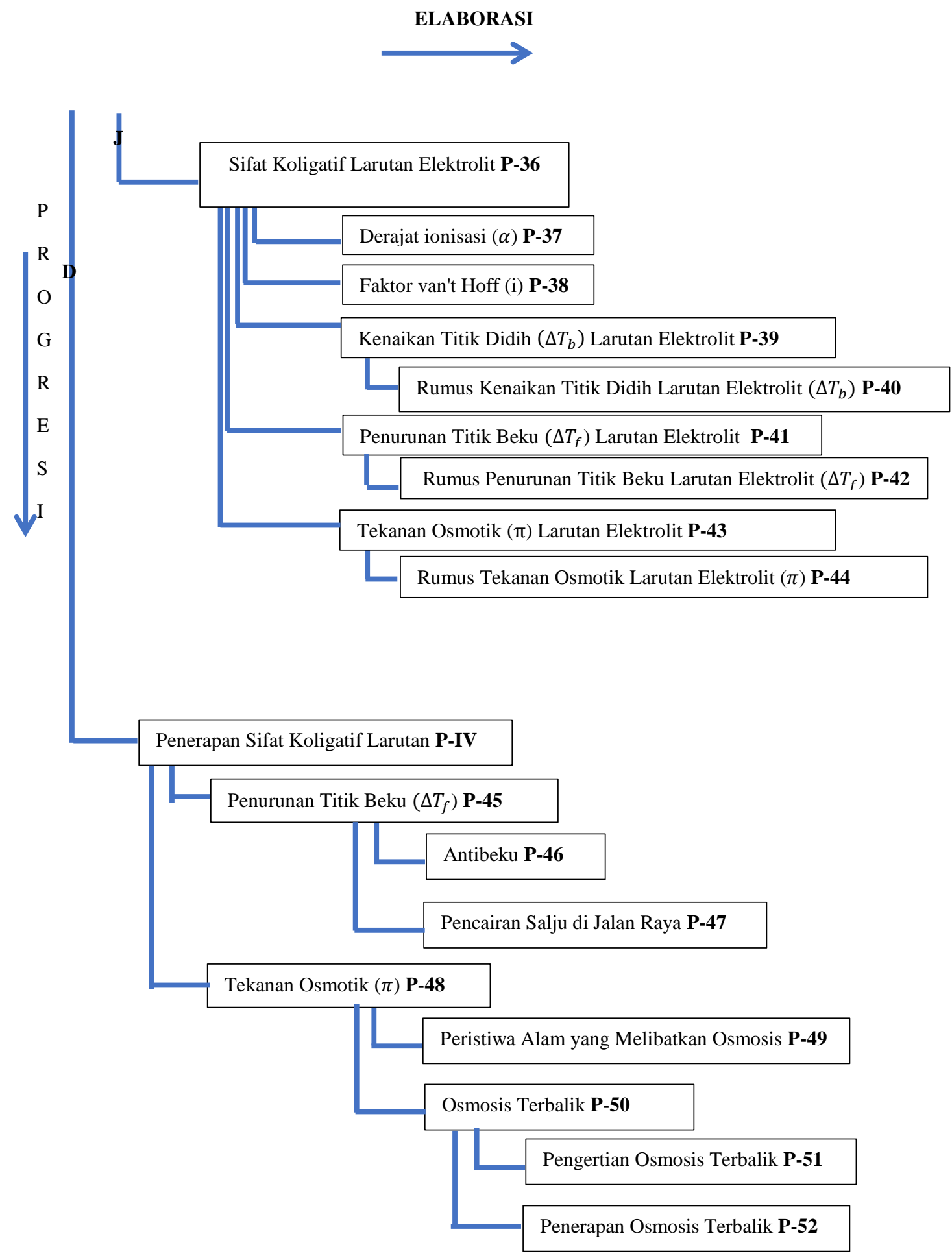

Gambar 5. Struktur Makro Wacana Buku Teks B (Lanjutan) 
Struktur makro wacana pada buku teks A dan buku teks B label konsep konsentrasi larutan pada dimensi elaborasi mencapai level 4, label konsep pengertian sifat koligatif larutan mencapai level 3, label konsep jenis-jenis sifat koligatif larutan mencapai level 6, dan label konsep penerapan sifat koligatif larutan mencapai level 4. Dimensi progresi pada kedua buku teks terletak pada level 2 terdapat 4 konsep. Pada buku teks A, proposisi berpotensi kesalahan konsep yaitu proposisi tekanan osmotik $(\pi)$, penurunan titik beku $\left(\Delta \mathrm{T}_{\mathrm{f}}\right)$ dan kenaikan titik didih $\left(\Delta \mathrm{T}_{\mathrm{b}}\right)$ mengandung konsep prasyarat yang salah yaitu konsep yang menunjukkan atribut ukuran g (ukuran massa) dalam rumus. Buku teks B, proposisi berpotensi kesalahan konsep yang dibahas yaitu simbol kenaikan titik didih $\left(\Delta \mathrm{T}_{\mathrm{d}}\right)$, titik didih $\left(\mathrm{T}_{\mathrm{d}}\right)$, titik beku $\left(\mathrm{T}_{\mathrm{b}}\right)$, dan penurunan titik beku $\left(\Delta \mathrm{T}_{\mathrm{b}}\right)$. Beberapa contoh soal pada buku teks A dan B tidak menuliskan satuan.

\section{Kesimpulan}

Berdasarkan hasil penelitian dan pembahasan, kesimpulan yang didapatkan yaitu:

1. Jumlah label konsep pada buku teks A yaitu 46 buah dan jumlah label konsep pada buku teks B yaitu 40 buah. Label konsep pada penurunan tekanan uap yang menjadi konsep penting dari kedua buku teks yaitu pengertian penurunan tekanan uap $(\Delta \mathrm{P})$, rumus penurunan tekanan uap $(\Delta \mathrm{P})$, dan hukum raoult. Label konsep pada penurunan titik beku $\left(\Delta \mathrm{T}_{\mathrm{f}}\right)$ yaitu pengertian penurunan titik beku $\left(\Delta \mathrm{T}_{\mathrm{f}}\right)$, tetapan penurunan titik beku $\left(\mathrm{K}_{\mathrm{f}}\right)$, dan rumus penurunan titik beku $\left(\Delta \mathrm{T}_{\mathrm{f}}\right)$. Label konsep pada kenaikan titik didih yaitu pengertian kenaikan titik didih $\left(\Delta \mathrm{T}_{\mathrm{b}}\right)$, tetapan kenaikan titik didih $\left(\mathrm{K}_{\mathrm{b}}\right)$, dan rumus kenaikan titik didih $\left(\Delta \mathrm{T}_{\mathrm{b}}\right)$. Label konsep pada 
tekanan osmotik yaitu osmosis, pengertian tekanan osmotik $(\pi)$, isotonik, hipotonik, dan hipertonik, dan rumus tekanan osmotik $(\pi)$.

2. Struktur makro wacana pada buku teks A dan buku teks B dimensi elaborasi pada label konsep konsentrasi larutan mencapai level 4. Label konsep pengertian sifat koligatif larutan pada buku teks A mencapai level 3, pada buku teks B mencapai level 2. Label konsep jenis-jenis sifat koligatif larutan pada buku teks A dan buku teks B mencapai level 6, dan pada label konsep penerapan sifat koligatif larutan pada kedua buku teks mencapai level 4. Dimensi progresi kedua buku teks A dan buku teks B terdapat 4 label konsep pada level 2 yaitu konsentrasi larutan, pengertian sifat koligatif larutan, jenis-jenis sifat koligatif larutan, dan penerapan sifat koligatif larutan.

3. Pada buku teks A, proposisi berpotensi kesalahan konsep yaitu proposisi tekanan osmotik $(\pi)$, penurunan titik beku $\left(\Delta \mathrm{T}_{\mathrm{f}}\right)$ dan kenaikan titik didih $\left(\Delta \mathrm{T}_{\mathrm{b}}\right)$ mengandung konsep prasyarat yang salah yaitu konsep yang menunjukkan atribut ukuran g (ukuran massa) dalam rumus. Buku teks B, proposisi berpotensi kesalahan konsep yang dibahas yaitu simbol kenaikan titik didih $\left(\Delta \mathrm{T}_{\mathrm{d}}\right)$, titik didih $\left(\mathrm{T}_{\mathrm{d}}\right)$, titik beku $\left(\mathrm{T}_{\mathrm{b}}\right)$, dan penurunan titik beku $\left(\Delta \mathrm{T}_{\mathrm{b}}\right)$. Beberapa contoh soal pada buku teks $\mathrm{A}$ dan $\mathrm{B}$ tidak menuliskan satuan.

\section{Saran Penelitian}

Berdasarkan hasil penelitian, maka peneliti mengajukan beberapa saran antara lain: 
Sri Haryati Wulandari (300-320)

1. Guru agar lebih selektif dalam memilih buku teks yang akan digunakan dalam proses pembelajaran.

2. Bagi peneliti selanjutnya dapat melakukan penelitian lebih lanjut pada konsep-konsep lainnya dan membuat media pembelajaran berupa hiperteks untuk meningkatkan hasil belajar siswa pada topik yang sesuai dan menggunakan dalam pembelajaran.

\section{Daftar Pustaka}

Adisendjaja dan Romlah. 2007. Analisis Buku Ajar Sains Berdasarkan Literasi Ilmiah Sebagai Dasar Untuk Memilih Buku Ajar Sains (Biologi). Jurnal Pendidikan, 1, 18.

Anderson, L.W dan Krathwohl, D.R. 2010. Kerangka Landasan untuk Pembelajaran, Pengajaran dan Asesmen (Revisi Taksonomi Pendidikan Bloom). Yogyakarta: Pustaka Pelajar.

Arifin. 2008. Pembuatan Hiperteks Akademik Pada Materi Kajian Kecepatan Reaksi dan Pemanfaatannya Sebagai Media Pembelajaran Kimia di SMA. Palangka Raya: Universitas Palangka Raya.

Auliyani, A., Hanum, L., dan Khaldun, I. 2016. Analisis Kesulitan Pemahaman Siswa pada Materi Sifat Koligatif Larutan dengan Menggunakan ThreeTier Multiple Choice Diagnostic test di Kelas XII IPA 2 SMA Negeri 5 Banda Aceh. Jurnal Ilmiah Mahasiswa Pendidikan Kimia (JIMPK), 2(1): 55-64.

Berg, van den E. (Ed). 1991. Miskonsepsi Fisika dan Remediasi. Salatiga: Universitas Kristen Satya Wacana.

Bybee, R., McCrae, B., \& Laurie, R. 2009. PISA 2006: An assessment of scientific literacy. Journal of research in science teaching, 46(8): 865 88.

Chang, Raymond. 2003. Kimia Dasar Konsep-Konsep Inti Jilid 2 Edisi Keenam. Jakarta: Erlangga.

Departemen Pendidikan Nasional. 2008. Kamus Besar Bahasa Indonesia Pusat Bahasa, Edisi keempat. Jakarta: Penerbit PT Gramedia Pustaka Utama. 
Depdiknas. 2003. Kurikulum Kimia 2004. Jakarta: Departemen Pendidikan dan Kebudayaan Direktorat Jenderal Pendidikan Tinggi Proyek Pembinaaan Tenaga Kependidikan.

Dikmenli, M. 2009. Misconceptions of Cell Division Held by Student Teachers in Biology: A Drawing Analysis Scientific Research and Essays. Academic Journals Vol. 5: 235-247.

George, Yule. 2006. Pragmatik (edisi terjemahan oleh Indah Fajar Wahyuni dan Rombe Mustajab). Yogyakarta: Pustaka Pelajar.

Gkitzia, V., Salta, K, dan Tzougraki, C. 2010. "Development and Application of Suitable Criteria for the Evaluation of Chemical Represntatios in School Textboks", Chemistry Education Research and Practice, 12, 5-14.

Greene, H dan W.T. Petty. 1971. Developing Language Skills in the Elementary Schools. Boston: Allyn and Bacon, Inc.

Hamid, Darmadi. 2010. Kemampuan Dasar Mengajar. Bandung: Alfabeta.

Hersey, D.R. 2004. Avoid Misconception When Teaching about Plants. Diakses dari http://www.actionbioscience.org pada tanggal 17 Januari 2019.

Herron, J Dudley. 1977. Problem associated with concept analysis. JS E, 61(2), 185-199.

Kridalaksana, Harimurti. 2008. Kamus Linguistik. Jakarta: Gramedia Pustaka Utama.

Johnson, P. 1998. Children's Understanding of Changes of State Involving the Gas State, Part 1/ : Boiling Water and the Particle Theory. International Journal of Science Education, 20(5): 567-83.

Luoga, N, E., Ndunguru, P, A., and Mkoma, S, L. 2013. High School Student's Misconception about Colligative Properties in Chemistry, Tanzia Journal of Natural \& Aplied Sciences, 4(1): 575-581.

Marton, Ference. 1981. Phenomenography - Describing Conceptions of The Word Around Us. Instructional Science, 10: 177-200.

Novianto, A. 2015. Analisis Materi ajar Muatan Tematik Integratif, Scientific Different Representation Levels of Scientific Concepts. Dissertation. Hebwer University.

Paul, Suparno. 2013. Miskonsepsi dan Perubahan Konsep Pendidikan Fisika. Jakarta: Grasindo. 
Pinarbasari, T., Sozbilir, M., Canpolat, N. 2009. Prospective chemistry teachers' misconception about colligative properties: boiling point elevation and freezing point depression. Chemistry Education Research and Practice. 10: $273-280$.

Pranowo. 1996. Analisis Pengajaran Bahasa. Yogyakarta: Gadja Mada University Press.

Prastowo, Andi. 2013. Panduan Kreatif Membuat Bahan Ajar Inovatif. Yogyakarta: Diva Press.

Rahmidi, T. dan Teguh, P. 2009. Kimia 3 Untuk SMA/MA Kelas XII. Jakarta: Penerbit Grahadi.

Rosser, R. A. and Nicholson, G. L. 1984. Educational Psychology, Principles in Practise. Boston: Little Brown.

S. Nasution. 1992. Berbagai Pendekatan dalam Proses Belajar dan Mengajar. Jakarta: Radar Jaya Offset.

Sothayapetch, P. 2013. A Comparative Study of Science Education at The Primary School Level in Finland And Thailand. (Desertasi, University of Helsinki, Finlandia). Diakses dari https://helda.helsinki.fi/bitstream/handle/10138/42259/sothayapetch_disser tation.pdf?sequence $=1$

Sudarmo, Unggul. 2007. Kimia untuk SMA Kelas XII. Jakarta: PT. Phibeta Aneka Gama.

Sugihartono, Katika, N. F., Farida, H., Farida, A. S., Siti, R. N. 2006. Psikologi Pendidikan. Yogyakarta: FIP UNY.

Sungkono, 2012. Pendayagunaan Sumber Belajar Dalam Proses Pembelajaran. Jurnal Online.

Swanepoel, S. 2010. The assessment of the quality of science education textbooks: conceptual framework and instruments for analysis. Dissertation: University of South Africa.

Syah, Darwin. 2007. Perencanaan System Pengajaran Pendidikan Agama Islam. Jakarta: Gaung Persada Press.

Talanquer, V. 2009. Exploring dominant type of explanations built by general chemistry students. International Journal of Science Education. 32(18): 2393-2412. 
Tarigan, H. G. dan Tarigan, D. 2009. Telaah Materi Ajar Bahasa Indonesia. Bandung: Angkasa.

Toharudin, U., Hendrawati, S., dan Rustaman Andrian. (2011). Membangun Literasi Sains Peserta Didik. Bandung: Humaniora.

Yulia, Y dan Janti GS. 2009. Pengembangan Koleksi. Jakarta: Universitas Terbuka.

Zulkarnain, Andi. 2016. Pengembangan E-Modul Teori Atom Mekanika Kuantum Berbasis Web dengan Pendekatan Saintifik. Jurnal Penelitian. Lampung: Prodi Kimia FKIP Universitas Palangka Raya. 